\section{N, P, and K Rates and Leaf Tissue Standards for Optimum Anthurium andraeanum Flower Production}

\author{
Tadashi Higaki, Joanne S. Imamura ${ }^{2}$, and Robert E. Paull ${ }^{3}$ \\ College of Tropical Agriculture and Human Resources, University of \\ Hawaii, 461 West Lanikaula Street, Hilo, HI 96720
}

Additional index words. nutrition, fertilizer rates, field-grown anthuriums

\begin{abstract}
The optimum fertilizer levels of $\mathrm{N}, \mathrm{P}$, and $\mathrm{K}$ for flower production of fieldgrown Anthurium andraeanum Andre in Hawaii were determined. Applications were at 0,224 , and $448 \mathrm{~kg} \cdot \mathrm{ha}^{-1} \cdot \mathrm{year}^{-1}$ with all combinations of each nutrient level. Optimum flower production was achieved at $312 \mathrm{~N}-448 \mathrm{P}-375 \mathrm{~K} \mathrm{~kg} \cdot \mathrm{ha}^{-1} \cdot \mathrm{year}^{-1}$. Increased $\mathrm{N}$ and $K$ application resulted in a linear increase in flower size. Flower stem length also increased with increasing $\mathbf{N}, \mathbf{P}$, and $\mathrm{K}$ rates. Maximum flower yield occurred when leaf-tissue levels were $1.87 \% \mathrm{~N}, 0.17 \% \mathrm{P}$, and $2.07 \% \mathrm{~K}$. Flower stem length and flower size were at their maximum with leaf $N$ at $1.59 \%$ and $1.67 \%$ and $K$ at $2.20 \%$ and $1.86 \%$, respectively. No relationship was observed between leaf percent $P$, flower size, or stem length. A range of leaf-tissue levels associated with optimum anthurium flower production was determined for $\mathrm{Ca}, \mathrm{Mg}, \mathrm{B}, \mathrm{Mn}, \mathrm{Fe}, \mathrm{Zn}, \mathrm{Cu}$, and $\mathrm{Mo}$ ).
\end{abstract}

Various liquid, granular, organic, inorganic, and slow release fertilizers have been tested on Anthurium andraeanum cultivars with satisfactory results and with few differences observed in yield and flower quality (Poole and McConnell, 1971; Poole, et al., 1968). Recommended fertilizer rates for optimum production of field-grown anthuriums in various media have been in the range of 224 to $448 \mathrm{~kg}$ each of N-P-K/ha per year, with possibly higher rates for larger flowers and longer flower stems (Higaki and Imamura, 1985a, 1985b; Higaki and Poole, 1978). Bik (1976) conducted a factorial trial that included four $\mathrm{N}(125,216,306$, and 396 $\mathrm{mg} /$ pot per week) and three $\mathrm{K}_{2} \mathrm{O}(19,225$, and $431 \mathrm{mg} /$ pot per week) rates on anthurium potted plants grown in peat medium. Flower production, flower fresh weight, and flower stem length were adversely affected by an increase in $\mathrm{N}$ over the lowest rate tested. The two highest $\mathrm{K}$ rates produced highest yield, fresh flower weight, and stem length. An interaction was observed between $\mathrm{N}$ and $\mathrm{K}$ effects on flower size, with the lower $\mathrm{N}$ and higher $\mathrm{K}$ combinations producing the largest flowers. Bik (1976) concluded that anthuriums, in sphagnum peat, should be fertilized with $\mathrm{N}$ and $\mathrm{K}_{2} \mathrm{O}$ in a 1:2.5 ratio. The corresponding nutrient contents in the

Received for publication 10 July 1991. Accepted for publication 27 April 1992. Journal Series no. 3687 of the Univ. of Hawaii College of Tropical Agriculture and Human Resources. The use of trade names does not represent endorsement to the exclusion of equivalent material. The technical assistance of Dennis Ida is gratefully acknowledged The cost of publishing this paper was defrayed in part by the payment of page charges. Under postal regulations, this paper therefore must be hereby marked advertisement solely to indicate this fact. ${ }^{1}$ Horticulturist.

${ }^{2}$ Research Associate, Dept. of Horticulture.

${ }^{3}$ Plant Physiologist, Dept. of Plant Molecular Physiology. anthurium.
Mg. In fertilizer tests with 'Marian Seefurth', satisfactory yield was obtained when the $\mathrm{N}$ level in the second youngest leaf was $1.70 \%$ to $2.11 \%$, $\mathrm{P}$ was $0.21 \%$ to $0.58 \%$, and $\mathrm{K}$ was $2.05 \%$ to $3.16 \%$, with $\mathrm{N}$ being the limiting factor (Poole, et al. 1968). Low $\mathrm{Zn}(85 \mathrm{ppm})$ and $\mathrm{Fe}(86 \mathrm{ppm})$ levels were not limiting for flower production.

Field trials to determine specific N, P, and $\mathrm{K}$ requirements have not been reported. The following experiment was conducted at Hilo, Hawaii, using similar conditions used by the Hawaii anthurium commercial growers. The fertilizer rate for $\mathrm{N}, \mathrm{P}$, and $\mathrm{K}$ and the critical leaf nutrient concentration for optimum production of anthurium cut flowers were determined.

The experiment was conducted at the Waiakea Agricultural Experiment Station in Hilo, with $80 \%$ polypropylene shade. Fertilizer rates for $\mathrm{N}, \mathrm{P}$, and $\mathrm{K}$ were 0,224 , and $448 \mathrm{~kg} \cdot \mathrm{ha}^{-1} \cdot \mathrm{year}^{-1}$ with all combinations of each nutrient level. Slow-release granules, Osmocote (Sierra Chemical Co., Milpitas; Calif.) 39-0-0 and 0-0-45, were used to supply N and K, respectively. Phos-

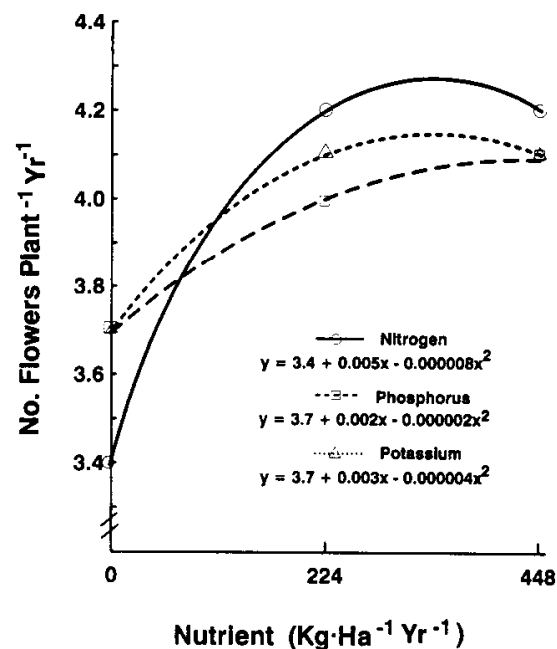

Fig. 1. Influence of N, P, and K levels on 'Ozaki' anthurium flower production.

Table 1. Single degree-of-freedom contrasts of the effects of N, P, and K on flower yield of 'Ozaki'

\begin{tabular}{|c|c|c|c|}
\hline Source & df & SS & $\mathbf{F}$ \\
\hline $\mathbf{N}$ linear (L) & 1 & 12.835 & $253.5^{* * *}$ \\
\hline $\mathbf{N}$ quadratic $(\mathrm{Q})$ & 1 & 4.002 & $79.0^{* * *}$ \\
\hline$P$ linear $(L)$ & 1 & 2.311 & $45.6^{* * *}$ \\
\hline $\mathrm{P}$ nonlinear (Q) & 1 & 0.570 & $11.3^{* *}$ \\
\hline $\mathrm{K}$ linear (L) & 1 & 3.555 & $70.2^{* * *}$ \\
\hline $\mathrm{K}$ nonlinear $(\mathrm{Q})$ & 1 & 0.807 & $15.9^{* * *}$ \\
\hline $\mathrm{NL} \times \mathrm{PL}$ & 1 & 0.075 & $1.5 \mathrm{NS}$ \\
\hline $\mathrm{NL} \times \mathrm{PQ}$ & 1 & 0.037 & $0.7 \mathrm{NS}$ \\
\hline $\mathrm{NQ} \times \mathrm{PL}$ & 1 & 0.076 & $1.5 \mathrm{NS}$ \\
\hline $\mathrm{NQ} \times \mathrm{PQ}$ & 1 & 0.005 & $0.1 \mathrm{NS}$ \\
\hline $\mathrm{NL} \times \mathrm{KL}$ & 1 & 0.003 & $0.1 \mathrm{NS}$ \\
\hline $\mathrm{NL} \times \mathrm{KQ}$ & 1 & 0.100 & $2.0 \mathrm{NS}$ \\
\hline $\mathrm{NQ} \times \mathrm{KL}$ & 1 & 0.071 & $1.4 \mathrm{NS}$ \\
\hline $\mathrm{NQ} \times \mathrm{KQ}$ & 1 & 0.067 & $1.3 \mathrm{NS}$ \\
\hline $\mathrm{PL} \times \mathbf{K L}$ & 1 & 0.053 & $1.0 \mathrm{NS}$ \\
\hline $\mathrm{PL} \times \mathrm{KQ}$ & 1 & 0.000 & $0.0 \mathrm{NS}$ \\
\hline $\mathrm{PQ} \times \mathrm{KL}$ & 1 & 0.134 & $2.7 \mathrm{NS}$ \\
\hline $\mathrm{PQ} \times \mathrm{KQ}$ & 1 & 0.003 & $0.1 \mathrm{NS}$ \\
\hline Residual & 8 & 0.499 & $1.2 \mathrm{NS}$ \\
\hline
\end{tabular}

Ns $* * * * * * * *$ Nonsignificant or significant at $\mathrm{P} \leq 0.05,0.01$, or 0.001 , respectively. 


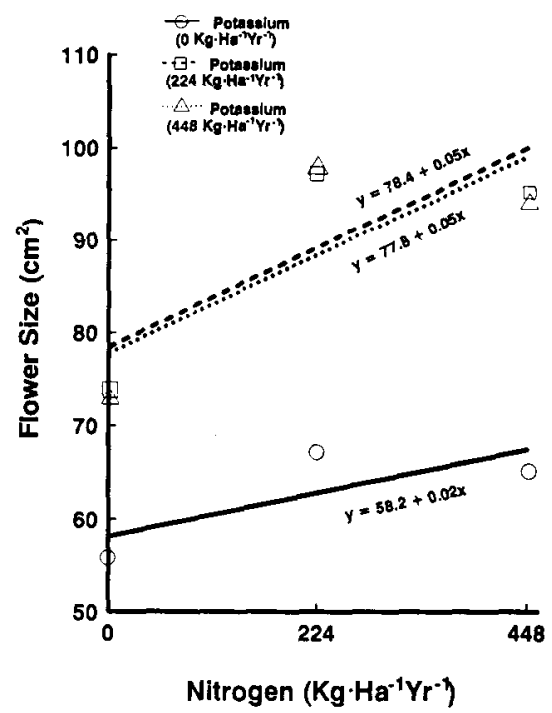

Fig. 2. Effect of interaction of $\mathrm{N}$ and $\mathrm{K}$ levels on 'Ozaki' anthurium flower size.

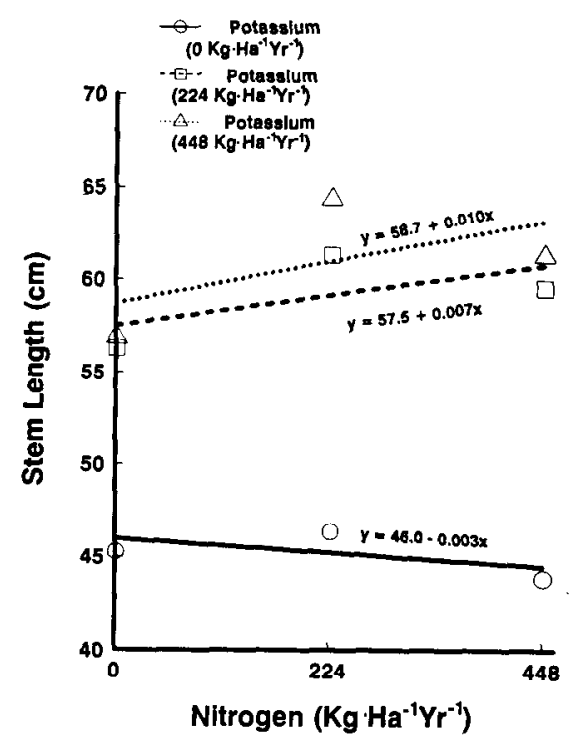

$\overline{\text { Fig. }}$ 3. Êffect of interaction of $\overline{\mathrm{N}}$ and $\overline{\mathrm{K}}$ levels on 'Ozaki' anthurium flower stem length.
Table 2. Single degree-of-freedom contrasts of effects of N, P, and K on flower size of 'Ozaki' anthurium.

\begin{tabular}{|c|c|c|c|}
\hline Source & $\mathrm{df}$ & SS & F \\
\hline $\mathrm{N}$ linear $(\mathrm{L})$ & 1 & 5400.030 & $86.3^{* * *}$ \\
\hline$N$ quadratic $(Q)$ & 1 & 2921.774 & $46.7^{* * *}$ \\
\hline$P$ linear $(\mathrm{L})$ & 1 & 166.258 & $2.7 \mathrm{NS}$ \\
\hline $\mathrm{P}$ nonlinear $(\mathrm{Q})$ & 1 & 69.417 & $1.1 \mathrm{NS}$ \\
\hline $\mathrm{K}$ linear $(\mathrm{L})$ & 1 & 11737.929 & $187.5^{* * *}$ \\
\hline $\mathbf{K}$ nonlinear $(Q)$ & 1 & 4451.470 & $71.1^{* *}$ \\
\hline $\mathrm{NL} \times \mathrm{PL}$ & 1 & 3.307 & $0.1 \mathrm{NS}$ \\
\hline $\mathrm{NL} \times \mathrm{PQ}$ & 1 & 46.808 & $0.7 \mathrm{NS}$ \\
\hline$N Q \times P L$ & 1 & 0.015 & $0.0 \mathrm{NS}$ \\
\hline $\mathrm{NQ} \times \mathrm{PQ}$ & 1 & 13.469 & $0.2 \mathrm{NS}$ \\
\hline $\mathrm{NL} \times \mathrm{KL}$ & 1 & 435.126 & $6.9^{*}$ \\
\hline $\mathrm{NL} \times \mathrm{KQ}$ & 1 & 154.712 & $2.5 \mathrm{Ns}$ \\
\hline $\mathrm{NQ} \times \mathrm{KL}$ & 1 & 224.051 & $3.6 \mathrm{NS}$ \\
\hline $\mathrm{NQ} \times \mathrm{KQ}$ & 1 & 12.174 & $0.2 \mathrm{NS}$ \\
\hline $\mathrm{PL} \times \mathrm{KL}$ & 1 & 30.976 & $0.5 \mathrm{NS}$ \\
\hline $\mathrm{PL} \times \mathrm{KQ}$ & 1 & 3.516 & $0.1 \mathrm{NS}$ \\
\hline $\mathrm{PQ} \times \mathrm{KL}$ & 1 & 1.292 & $0.0 \mathrm{NS}$ \\
\hline $\mathrm{PQ} \times \mathrm{KQ}$ & 1 & 216.382 & $3.5 \mathrm{NS}$ \\
\hline Residual & 8 & 368.861 & $0.7 \mathrm{NS}$ \\
\hline
\end{tabular}

${ }^{\mathrm{Ns}},{ }^{*},{ }^{*}, * * *$ Nonsignificant or significant at $\mathrm{P} \leq 0.05,0.01$, or 0.001 , respectively.

Table 3. Single degree-of-freedom contrasts of effects of N, P, and K on flower stem length of 'Ozaki' anthurium.

\begin{tabular}{|c|c|c|c|}
\hline Source & df & SS & $\mathrm{F}$ \\
\hline $\mathrm{N}$ linear (L) & 1 & 77.087 & $5.7 *$ \\
\hline $\mathrm{N}$ quadratic (Q) & 1 & 284.052 & $21.1^{* * *}$ \\
\hline$P$ linear $(L)$ & 1 & 146.062 & $10.8^{* *}$ \\
\hline P nonlinear (Q) & 1 & 42.285 & $0.1 \mathrm{NS}$ \\
\hline $\mathrm{K}$ linear (L) & 1 & 4448.603 & $329.2^{* * *}$ \\
\hline $\mathrm{K}$ nonlinear $(\mathrm{Q})$ & 1 & 888.126 & $65.7^{* * *}$ \\
\hline $\mathrm{NL} \times \mathrm{PL}$ & 1 & 1.534 & 0.1 NS \\
\hline$N L \times P Q$ & 1 & 2.953 & $0.2 \mathrm{NS}$ \\
\hline $\mathrm{NQ} \times \mathrm{PL}$ & 1 & 2.156 & $0.2 \mathrm{NS}$ \\
\hline $\mathrm{NQ} \times \mathrm{PQ}$ & 1 & 0.109 & $0.0 \mathrm{NS}$ \\
\hline $\mathrm{NL} \times \mathrm{KL}$ & 1 & 102.580 & $7.6^{* *}$ \\
\hline $\mathrm{NL} \times \mathrm{KQ}$ & 1 & 12.490 & 0.9 NS \\
\hline $\mathrm{NQ} \times \mathrm{KL}$ & 1 & 48.476 & $3.6 \mathrm{NS}$ \\
\hline $\mathrm{NQ} \times \mathrm{KQ}$ & 1 & 0.004 & $0.0 \mathrm{NS}$ \\
\hline $\mathrm{PL} \times \mathrm{KL}$ & 1 & 63.710 & $4.7^{*}$ \\
\hline $\mathrm{PL} \times \mathrm{KQ}$ & 1 & 1.668 & 0.1 NS \\
\hline $\mathrm{PQ} \times \mathrm{KL}$ & 1 & 4.060 & $0.3 \mathrm{NS}$ \\
\hline$P Q \times K Q$ & 1 & 27.654 & $2.0 \mathrm{NS}$ \\
\hline Residual & 8 & 73.441 & $0.7 \mathrm{NS}$ \\
\hline
\end{tabular}

Ns,*******Nonsignificant or significant at $P \leq 0.05,0.01$, or 0.001 , respectively.

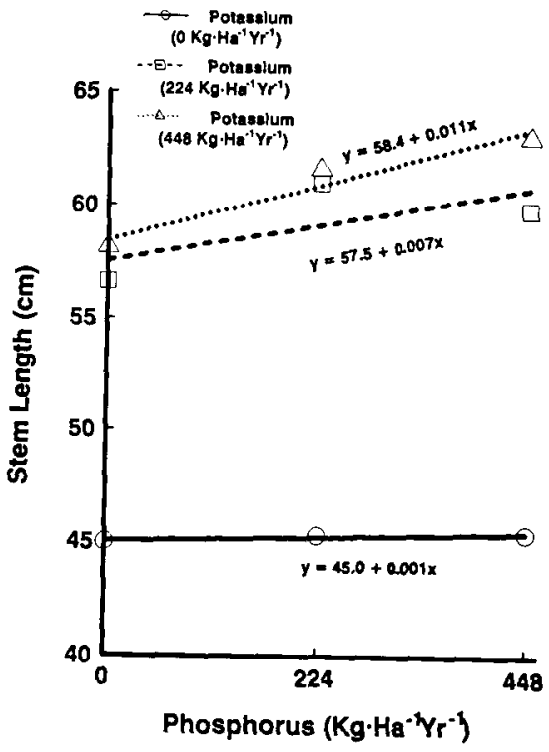

Fig. 4. Effect of interaction of $\mathrm{P}$ and $\mathrm{K}$ levels on 'Ozaki' anthurium flower stem length.

phorus was supplied as treble superphosphate $(0-46-0)$. Fertilizer was applied in three equal applications per year at 4-month intervals. Each treatment was replicated four times in a randomized complete-block design. The experimental unit consisted of five mature anthurium 'Ozaki' plants established in cinder medium in a $2 \times 0.6 \mathrm{~m}$ plot. Calcium, as dolomite, was supplied once a year at 448 $\mathrm{kg} \cdot \mathrm{ha}^{-1} \cdot \mathrm{year}^{-1}$, and plants were irrigated with overhead sprinklers at $\approx 100,000$ liters-ha-1-day-‘. Insecticides were applied as required.

Biweekly data collection began in Apr. 1983, 6 months after application of the first fertilizer treatment and continued for 3 years. Flower production, flower stem length (taken from the base of the stem to the point of spathe attachment), and spathe size (calculated as the product of the spathe length and width) were taken from the mother plant only. Leaf tissue samples were taken annually from each plot. Leaves subtending a three-fourths matured flower were used as the index tissue. Flower maturity was determined by the degree of color change of the spadix (Paull, 1982). Leaf laminae were excised, washed with distilled water, oven dried, ground, and analyzed with an X-ray fluorescent quantometer (Applied Research Laboratories, Sunland, Calif.). Treatments with $\mathrm{N}, \mathrm{P}$, or $\mathrm{K}$ at $0 \mathrm{~kg} \cdot \mathrm{ha}^{-1} \cdot \mathrm{year}^{-1}$ were excluded from analysis in determining leaf tissue standards. Data were subjected to single degree-of-freedom contrasts and regression analysis using General Linear Models (GLM) procedures (SAS Institute, Cary, N.C.).

Flower production. There was no interaction between the effects of N, P, and $\mathrm{K}$ on the number of flowers produced per plant per year (Table 1). Yield increased quadratically in response to increases in $\mathrm{N}, \mathrm{P}$, and $\mathrm{K}$ applications (Fig. 1). These findings agree with published results (Higaki and Imamura, 1985a, 1985b; Higaki and Poole, 1978; Poole and Greaves, 1969) in that the best flower 

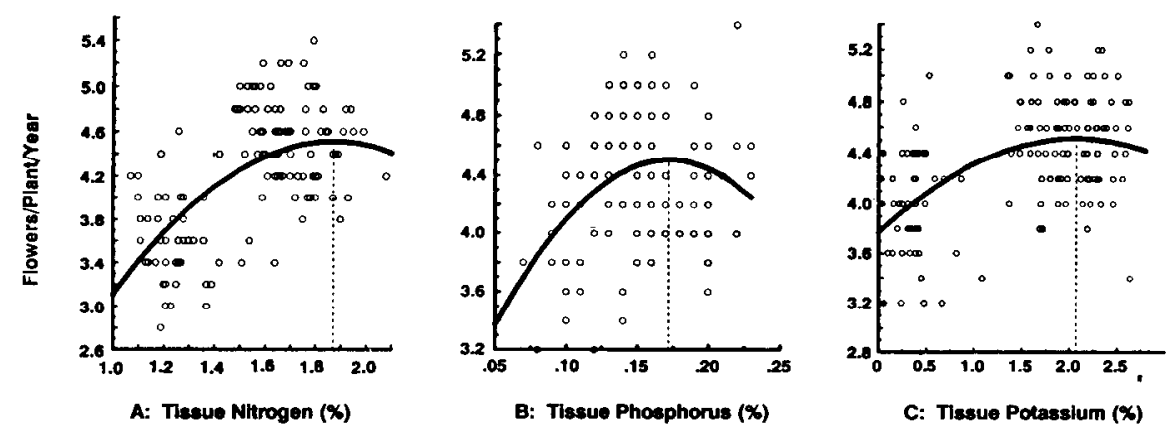

Fig. 5. Relation of 'Ozaki' anthurium flower yield to percent $\mathrm{N}, \mathrm{P}$, and $\mathrm{K}$ in leaves. Data points are mean number of flowers per plant per plot per year. (A) $\mathrm{Y}=-1.98+6.95 \mathrm{x}-1.86 \mathrm{x}^{2} . R^{z}=$ 0.40. (B) $\mathrm{Y}=2.25+26.24 \mathrm{x}-76.24 \mathrm{x}^{2} \cdot R^{2}=0.14$. (C) $\mathrm{Y}=3.77+0.72 \mathrm{x}-0.17 \mathrm{x}^{2} \cdot R^{2}=$ 0.26 .
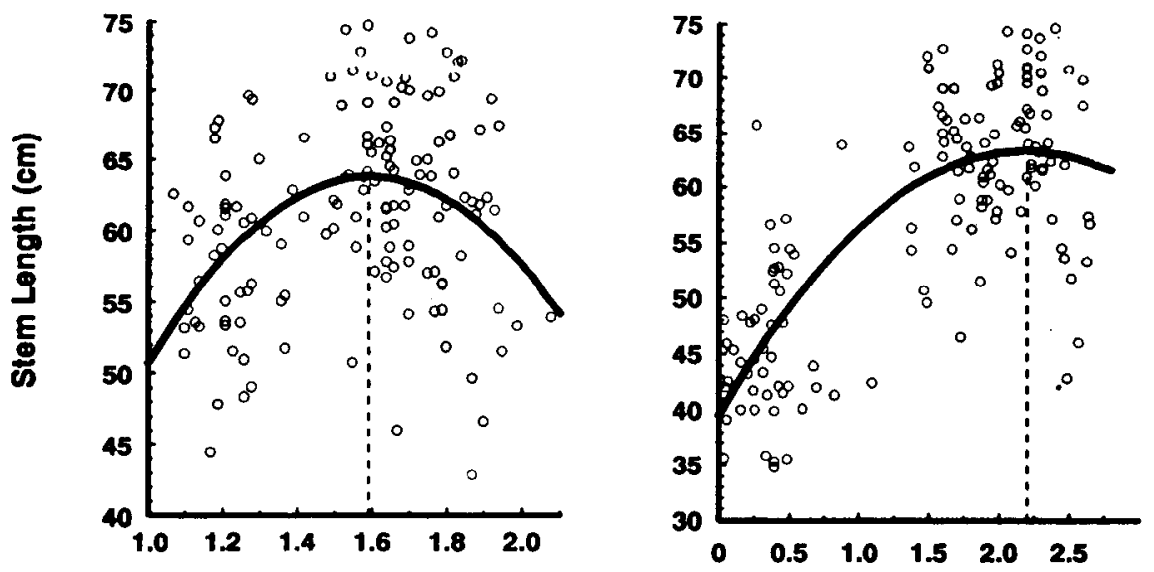

A: Tissue Nitrogen (\%)

B: Tissue Potassium (\%)

Fig. 6. Relation of 'Ozaki' anthurium flower stem length to percent $\mathrm{N}$ and $\mathrm{K}$ in leaves. Data points are mean flower stem lengths per plot per year. (A) $\mathrm{Y}=-12.23+46.90 \mathrm{x}-14.71 \mathrm{x}^{2} \cdot R^{2}=$ 0.15 . (B) $\mathrm{Y}=15.57+8.57 \mathrm{x}-1.96 \mathrm{x}^{2} \cdot R^{2}=0.57$.

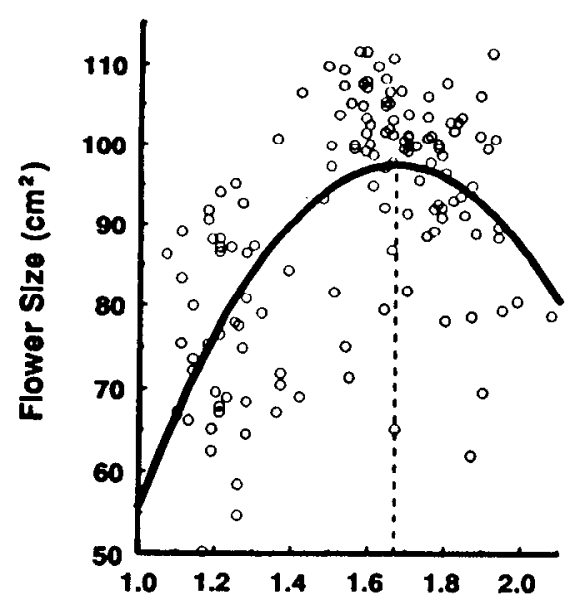

A: Tlesue Nitrogen (\%)

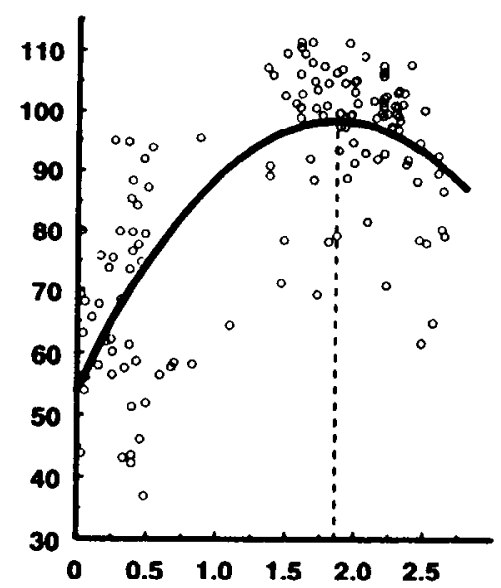

B: Tissue Potaselum (\%)

Fig. 7. Relation of 'Ozaki' anthurium flower size to percent $\mathrm{N}$ and $\mathrm{K}$ in leaves. Data points are mean flower sizes per plot per year. (A) $\mathrm{Y}=-63.47+121.82 \mathrm{x}-36.4 \mathrm{x}^{2} \cdot R^{z}=0.40$. (B) $\mathrm{Y}=21.28$ $+18.75 \mathrm{x}-5.06 \mathrm{x}^{2} \cdot R^{2}=0.56$

production was associated with $\mathrm{N}$ rates between 224 and $448 \mathrm{~kg} \cdot \mathrm{ha}^{-1} \cdot \mathrm{year}^{-1}$, with $\mathrm{N}$ for maximum yield calculated as $\mathrm{X}_{\max }=-\mathrm{b} /$ 2c or $312.5 \mathrm{~kg}$ (Little and Hill, 1978). Maximum yield was also associated with $\mathrm{K}$ rates between 224 and $448 \mathrm{~kg} \cdot \mathrm{ha}^{-1} \cdot \mathrm{year}^{-1}(\mathrm{X}$, $=375 \mathrm{~kg}$ ). An increase in $\mathrm{P}$ rates over that used in this study could possibly increase yield further and should be investigated.

Flower size. Flower size was affected by $\mathrm{N}$ and $\mathrm{K}$ rates but showed no response to $\mathrm{P}$ (Table 2). The interaction reported between $\mathrm{N}$ and K by Bik (1976) was also observed in this study. Increase in $\mathrm{N}$ and $\mathrm{K}$ fertilizer rates resulted in a linear increase in flower size (Fig. 2). This result is consistent with those obtained by Higaki and Poole (1978), where the largest flowers were obtained at $\mathrm{N}$ and $\mathrm{K}$ rates of 896 and $740 \mathrm{~kg} \cdot \mathrm{ha}^{-1} \cdot \mathrm{year}^{-1}$, respectively. All flowers produced with levels of $\mathrm{N}$ and $\mathrm{K}$ at $448 \mathrm{~kg} \cdot \mathrm{ha}^{-1} \cdot \mathrm{year}^{-1}$ would be commercially classified as large (Hawaii Dept. of Agriculture, 1984).

Flower stem length. Interactions between $\mathrm{N}$ and $\mathrm{K}$ and $\mathrm{P}$ and $\mathrm{K}$ were observed (Table 3 ), with lack of $\mathrm{K}$ having the greatest influence on flower stem length response to $\mathrm{N}$ (Fig. 3) and to P (Fig. 4). All flower stem lengths met the minimum Hawaii grade standards of $38.1 \mathrm{~cm}$ (Hawaii Dept. of Agriculture, 1984). However, florists prefer a stem length of $\approx 55$ to $60 \mathrm{~cm}$, which can be obtained with 224 to $448 \mathrm{~kg} \cdot \mathrm{ha}^{-1} \cdot \mathrm{year}^{-1}$ each of $\mathrm{N}, \mathrm{P}$, and $\mathrm{K}$.

The optimum fertilizer rate combinations for production of field-grown anthurium cut flowers in this study was $312 \mathrm{~N}-448 \mathrm{P}-375 \mathrm{~K}$ kg-ha-l-year-1.

Leaf tissue analysis. Hershey and Paul (1981) suggested that the critical tissue level associated with maximum yield or $90 \%$ of the maximum yield be used for management of fertilization programs for floricultural crops. We used maximum yields. Relationships were curvilinear between leaf concentrations of $\mathrm{N}$ $(\mathrm{P}=0.01), \mathrm{P}(P=0.001)$, and $\mathrm{K}(P=$ $0.05)$ and number of flowers produced per plant per year (Fig. 5). Critical nutrient levels associated with maximum anthurium yield calculated from these plots were $1.87 \% \mathrm{~N}$ (Fig. 5A), 0.17\% P (Fig. 5B), and $2.07 \% \mathrm{~K}$ (Fig 5C). Results for critical $\mathrm{N}$ level were within the published ranges (Poole and Greaves, 1969; Poole, et al., 1968). Bik (1976) reported a higher $\mathrm{N}$ level but felt that the amount of $\mathrm{N}$ applied in his study was optimum or above. The $0.17 \% \mathrm{P}$ obtained was in agreement with that of Poole and Greaves (1969). Poole et al. (1968) reported a higher $\mathrm{P}$ level, but as $\mathrm{P}$ had no effect on yield, their rates may have been in the luxury consumption range for anthuriums. The $\mathrm{K}$ levels reported by other researchers had a much wider range than those for $\mathrm{N}$ or $\mathrm{P}$. The $\mathrm{K}$ level we obtained was within the range reported by Poole et al. (1968), but higher than that reported by Poole and Greaves (1969) and lower than that of Bik (1976). Poole and Greaves (1969) attributed their low $\mathrm{K}$ level $(1.1 \%)$ to insufficient nutrient levels of $\mathrm{K}$ tested. The much higher $\mathrm{K}$ level (3.0\%) reported by Bik (1976) may have been above optimum as he found a quadratic response of yield to the increased $\mathrm{K}$ levels. The correlation between leaf concentrations of $\mathrm{P}$ and $\mathrm{K}$ and yield was relatively low in our study, thus a wider range for critical levels of $\mathrm{P}$ and $\mathrm{K}$ may be more appropriate for use as a reference for yield. In general, the critical levels for $\mathrm{N}, \mathrm{P}$, and $\mathrm{K}$ obtained by different researchers using various cultivars were similar. Differences could be accounted for by the fact that the ages of the leaves used were not the same. Poole et al. (1968) found that $\mathrm{N}, \mathrm{P}$, and $\mathrm{K}$ levels in leaf blades generally decreased with an increase in leaf age. 
Table 4. Foliar levels of elements in anthurium at maximum production $25 \%$.

\begin{tabular}{lcccc}
\hline \hline Element & Minimum & Maximum & Mean & SD \\
\hline & & Percent & & \\
$\mathrm{Ca}$ & 0.46 & 2.93 & 1.08 & 0.33 \\
$\mathrm{Mg}$ & 0.20 & 0.88 & 0.28 & 0.08 \\
$\mathrm{~S}$ & 0.13 & 0.35 & 0.21 & 0.03 \\
$\mathrm{Si}$ & 0.00 & 0.07 & 0.02 & 0.02 \\
$\mathrm{Na}$ & 0.02 & 0.44 & 0.08 & 0.05 \\
& & $p p m$ & & \\
$\mathrm{NO}_{3}$ & 164 & 3090 & 1470 & 668 \\
$\mathrm{~B}$ & 8.00 & 166 & 22.1 & 15.9 \\
$\mathrm{Mn}$ & 100 & 373 & 195 & 57.0 \\
$\mathrm{Fe}$ & 0.00 & 129 & 90.0 & 32.6 \\
$\mathrm{Zn}$ & 14.0 & 181 & 40.4 & 17.2 \\
$\mathrm{Al}$ & 1.00 & 509 & 54.6 & 98.7 \\
$\mathrm{Cu}$ & 3.00 & 26.0 & 9.24 & 3.31 \\
$\mathrm{Mo}$ & 0.00 & 5.00 & 1.89 & 1.67 \\
\hline
\end{tabular}

Curvilinear relationships $(\mathrm{P}=0.0001)$ were observed between $\mathrm{N}$ and $\mathrm{K}$ leaf contents and flower stem length (Fig. 6) and flower size (Fig. 7). Critical $\mathrm{N}$ and $\mathrm{K}$ levels obtained for maximum flower stem length were $1.59 \% \mathrm{~N}$ and $2.20 \% \mathrm{~K}$. Critical levels obtained for maximum flower size were $1.67 \% \mathrm{~N}$ and $1.86 \% \mathrm{~K}$. No relationship was found between leaf $\mathrm{P}$ and flower stem length or flower size.

These $\mathrm{N}$ and $\mathrm{K}$ levels differ from those obtained for maximum flower production and should be used if one is seeking to obtain maximum flower stem length and size at the risk of losing maximum flower production. However, it should be noted that at the critical levels for maximum flower production $(1.87 \% \mathrm{~N}$ and $2.07 \% \mathrm{~K})$, flowers met the Hawaii state minimum stem length standard requirement of $38.1 \mathrm{~cm}$ and the florists preference of 55 to $60 \mathrm{~cm}$ stem length. All flowers were in the "large" or "extra-large" size category (Hawaii Dept. of Agriculture, 1984).

Calcium, Mg, S, B, Mn, Fe, Zn, Cn, and
Mo concentrations were obtained from leaves where foliar N, P, and $\mathrm{K}$ levels were associated with maximum production $25 \%$ (Table 4$)$. The lowest level of $\mathrm{Ca}(0.46 \%)$ seems adequate for maximum flower production. However, to prevent the color breakdown disorder of anthurium flowers resulting from the lack of Ca, Higaki (1977) found that the critical level of $\mathrm{Ca}$ should be $70.54 \%$. The mean $\mathrm{Mg}$ concentration of $0.28 \%$ is similar to the $0.35 \%$ reported by Bik (1976) and Boertje (1978) and the $0.21 \%$ reported by Imamura and Higaki (1984), but is below the $0.75 \%$ recommended by Poole and Greaves (1969). The mean $\mathrm{S}$ concentration of $0.21 \%$ agrees with the adequate level of $0.19 \%$ reported earlier (Imamura and Higaki, 1984).

\section{Literature Cited}

Bik, Arnold R. 1976. Quality in Anthurium andreanum and Aechmea fasciata in peat substrate as affected by nitrogen and potassium nutrition. Acta Hort. 64:83-91.

Boertje, G.A. 1978. Substrates and the nutrition of Anthurium andreanum. Acta Hort. 82:159164.

Hawaii Dept. Agr. 1984. Minimum standards and grades for export requirements, anthurium flowers. Div. Mktg. Consumer Serv., Honolulu.

Hershey, D.R. and J.L. Paul. 1981. Critical foliar levels of potassium in pot chrysanthemum. HortScience 16:220-221.

Higaki, T. 1977. Calcium level in color breakdown disorder of anthurium flowers, Anthurium andreanum Lind. Proc. Trop. Reg. Amer. Soc. Hort. Sci. 21:44-45.

Higaki, T. and J.S. Imamura. 1985a. Performance of wood products as media for culture of anthuriums. Hawaii Inst. Trop. Agr. Human Resources Res. Ser. 040:1-8.

Higaki, T. and J.S. Imamura. 1985b. Volcanic black cinder as a medium for growing anthuriums. HortScience 20:298-300.

Higaki, T. and R.T. Poole. 1978. A media and fertilizer study in anthurium. J. Amer. Soc. Hort. Sci. 103:98-100

Imamura, J.S. and T. Higaki. 1984. Nutrient deficiency in anthuriums. Univ. of Hawaii, Hawaii Inst. Trop. Agr. Human Resources Res. Ext. Ser. 047

Little, T.M. and F.J. Hills. 1978. Agricultural experimentation. Design and analysis. Wiley, New York.

Paull, R.E. 1982. Anthurium (Anthurium andraeanum Andre) vase life evaluation criteria. HortScience 17:606-607.

Poole, R.T. and B.A. Greaves. 1969. Nitrogen, phosphorus and potassium fertilization of $\mathrm{An}$ thurium andreanum 'Nitta' and 'Kaumana'. Proc. Trop. Reg. Amer. Soc. Hort. Sci. 13:367-372.

Poole, R.T. and D.B. McConnell. 1971. Effects of shade levels and fertilization on flowering of Anthurium andreanum 'Nitta' and 'Kaumana'. Proc. Trop. Reg. Amer. Soc. Hort. Sci. 15:189195.

Poole, R.T., R. Sakuoka, and J.A. Silva. 1968 Nutrition of Anthurium andreanum. Proc. Trop. Reg. Amer. Soc. Hort. Sci. 12284-287. 